\title{
IMPLEMENTASI ASAS DISPENSASI KAWIN DI WILAYAH HUKUM PENGADILAN TINGGI AGAMA PALU PERSPEKTIF MASLAHAH
}

\author{
Massadi \\ Abd. Qadir Gassing \\ Usman Jafar \\ Kasjim Salenda \\ Pascasarjana UIN Alauddin Makassar \\ Jalan Trans Sulawesi Kecamatan Bungku Tengah Kabupaten Morowali. \\ Email : adjie.massadi@gmail.com
}

\begin{abstract}
Abstrak: The results of the study revealed that the degree of election of marriage dispensation in the jurisdiction of the Religious High Court of Palu was motivated by several factors, namely the pregnancy occurrence, parents' concerns, economic, matchmaking, and culture when was about to get married and still under-age so it had to firstly apply for dispensation of marriage to the religious court in accordance with Act No. 1 of 1974, Article 7 Paragraph (1) and (2) Concerning Marriage jo Compilation of Islamic Law Article 15 Paragraphs (1) and (2).

The application of marriage dispensation was submitted to the court, then will be on trial and judge's consideration in granting marriage dispensation which was not bound by the single positive law yet it was a consideration of justice, legal sociology and benefits that emphasized the implementation of maslahah principle as well.
\end{abstract}

Keywords: Marriage Dispensation, Judge, Maslahah.

\section{Pendahuluan}

Manusia merupakan mahluk bermasyarakat sehingga tidak akan bisa hidup tanpa hukum. Manusia dan hukum memiliki hubungan yang sangat erat dan saling ketergantungan seperti adanya antara ikan dan air yang berbeda namun selalu menyatu. Seorang filosof Romawi, Celcius, kurang lebih 20 abad yang silam menegaskan: ubi societas ibi ius (dimana ada masyarakat disitu ada hukum). ${ }^{1}$

Jiwa interaktif manusia mempunyai hubungan bahwa manusia hanya dapat berkembang, kalau hidup dalam polis. Polis terdiri dari unit-unit kecil sebagai bagian-bagiannya, unit kecil tersebut adalah keluarga, yaitu yang terdiri dari suami bersama dengan istri dan anak-anaknya. ${ }^{2}$

\footnotetext{
${ }^{1}$ F. Isjwara, Pengantar Ilmu Politik, (Jakarta, Bina Cipta, 1992), h.79.

${ }^{2}$ Agus Santoso, Hukum, Moral dan Keadilan, Sebuah Kajian Filsafat Hukum, (Jakarta: Prenada Media Group, 2012), h. 26.
} 
Membentuk dan membangun keluarga merupakan perintah yang telah ditetapkan Allah. Hikmahnya tiada lain agar terealisir kesinambungan hidup dalam kehidupan dan agar manuasia berjalan selaras dengan fitrahnya, dan dilakukan oleh orang yang telah mampu secara mental dan spiritual untuk membina rumah tangga. ${ }^{3}$

Perkawinan yang merupakan ikatan di antara dua insan yang mempunyai banyak perbedaan, baik dari segi fisik, asuhan keluarga, pergaulan, cara berpikir (mental), pendidikan dan lain hal. Dalam pandangan Islam, perkawinan adalah ikatan sangat suci dimana dua insan yang berlainan jenis dapat hidup bersama dengan direstui agama, kerabat dan masyarakat. ${ }^{4}$

Diciptakannya berpasang-pasangan merupakan pola hidup yang ditetapkan Allah swt., bagi makhluknya sebagai sarana untuk memperbanya (melanjutkan) keturunan dan mempertahankan hidup, yang mana masing-masing pasangan telah diberi bekal oleh Allah swt., untuk mencapai tujuan tersebut dengan sebaik mungkin. ${ }^{5}$

Berpasangan yang dimaksud di atas merupakan salah satu sunnatullah yang telah diberikan dan diperintahkan atas seluruh makhluknya, (QS. AdzDzariyat, 51:49.) dan (QS. Yasin 36; 36):

Perkawinan menurut hukum Islam adalah perkawinan, yaitu akad yang sangat kuat atau mitssaqan ghalidzan untuk mentaati perintah Allah dan melaksanakannya merupakan ibadah. Perkawinan bertujuan untuk mewujudkan kehidupan rumah tangga yang sakinah, mawaddah, dan rahmah ${ }^{6}$.

Indonesia adalah Negara Hukum ${ }^{7}$, dalam ketentuan aturan hukum perkawinan diatur dalam bentuk undang-undang yaitu undang-undang nomor 1 Tahun 1974 Tentang Perkawinan, dan peraturan pelaksanannya dalam bentuk Peraturan Pemerintah Nomor 9 Tahun 1975. Undang-undang ini merupakan hukum materil dari pada perkawinan, sedangkan hukum formalnya ditetapkan dalam Undang-Undang Nomor 7 Tahun 1989, tentang Peradilan Agama. Sedangkan aturan pelengkap yang akan menjadi pedoman bagi hakim di lembaga peradilan agama adalah Kompilasi Hukum Islam di Indonesia yang telah ditetapkan dan disebarluaskan melalui Intruksi Presiden Nomor 1 Tahun 1991 Tentang Kompilasi Hukum Islam. ${ }^{8}$

Di dalam undang-undang untuk menjembatani terwujudnya perkawinan yang sesuai dengan tujuan dari perkawinan, maka Undang-Undang Nomor 1

${ }^{3}$ M. Quraish Shihab, Tafsir al Misbah, Vol. IX. Jakarta : Lentera Hati, 2005, Cet. IV, h. 335

${ }^{4}$ Enseklopedia Pengetahuan Al-Qur'an dan Hadis, (Jakarta: Kamil Pustaka, 2013), h. 294-295.

${ }^{5}$ Sayyid Sabiq, Fiqh Sunnah, (Cakrawala Publising, 2008), h. 196.

${ }^{6}$ Intruksi Presiden Nomor 1 Tahun 1991, Tentang Kompilasi Hukum Islam, Pasal 2 dan 3.

${ }^{7}$ Undang-Undang Dasar 1945, Amandemen Ke- III, Pasal 1 Ayat 2.

${ }^{8}$ Amir Syarifudin, Hukum Perkawinan Islam di Indonesia, Antara Fiqh Munakahat dan Undang-Undang Perkawinan, (Cet. II; Jakarta: Prenada Media, 2007), h. 1 
Tahun 1974 tentang Perkawinan telah menentukan dan menetapkan dasar-dasar yang harus dilaksanakan dalam perkawinan. Salah satu di antaranya adalah Pasal 7 ayat (1) yang menyatakan, bahwa: "Perkawinan hanya diizinkan jika pihak pria sudah mencapai umur 19 (sembilan belas) tahun dan pihak wanita mencapai umur 16 (enam belas) tahun", dan dalam ayat selanjutnya menyatakan bahwa bila terdapat penyimpangan pada Pasal 7 ayat (1) dapat meminta dispensasi pada pengadilan atau pejabat lain yang ditunjuk oleh kedua belah pihak baik dari pihak pria atau pihak wanita. ${ }^{9}$

Permohonan dispensasi kawin yang di mohonkan ke Pengadilan Agama Donggala, Pengadilan Agama Parigi, Pengadilan Agama Buol dan Pengadilan Agama Bungku relatif meningkat setiap tahun pada tahun 2017. Di Pengadilan Agama Donggala klas Ib, dari perkara yang masuk sebanyak 1003 (seribu tiga) perkara, 10 (sepuluh) perkara diantaranya adalah permohonan dispensasi kawin. ${ }^{10}$ pada Pengadilan Agama Parigi klas II, dari perkara yang masuk sebanyak 436 (empat ratus tiga puluh enam) perkara, 25 (dua puluh lima) perkara diantaranya adalah permohonan dispensasi kawin ${ }^{11}$. Pada Pengadilan Agama Buol dari perkara yang masuk sebanyak 302 (tiga ratus dua) perkara, sementara 33 (tiga puluh tiga) perkara diantaranya adalah permohonan dispensasi kawin. ${ }^{12}$ Pada pengadilan Agama Bungku, dari perkara yang masuk sebanyak 515 (lima ratus lima) perkara, 17 (tujuh belas) perkara diantaranya adalah permohonan dispensasi kawin. ${ }^{13}$, yang mana perkara dispensasi kawin menjadi kewenangan absolut Pengadilan Agama ${ }^{14}$.

Dispensasi kawin ialah dispensasi yang diberikan Pengadilan Agama kepada calon mempelai yang belum cukup umur untuk melangsungkan perkawinan, bagi pria yang belum mencapai 19 (sembilan belas) tahun dan wanita belum mencapai 16 (enam belas) tahun. Dispensasi kawin diajukan oleh orang tua masing-masing. Pengajuan perkara permohonan dispensasi kawin dibuat dalam bentuk permohonan (voluntair) bukan gugatan. ${ }^{15}$

Mewujudkan keadilan yang berdasarkan Ketuhanan Yang Maha Esa, penegak hukum bukan hanya sekedar berperan memantapkan kepastian hukum, melainkan juga keadilan dan kemaslahatan. ${ }^{16}$

${ }^{9}$ Undang-Undang Nomor 1 Tahun 1974, Pasal 7 Ayat (1) dan (2) Tentang Perkawinan dan, Intruksi Presiden Nomor 1 Tahun 1991, Pasal 15 Ayat (1) dan (2) Tentang Kompilasi Hukum Islam.

${ }^{10}$ Laporan Perkara Pengadilan Agama Donggala Kelas IB Tahun 2017.

${ }^{11}$ Laporan Perkara Pengadilan Agama Parigi Kelas II Tahun 2017.

${ }^{12}$ Laporan Perkara Pengadilan Agama Buol Kelas II Tahun 2017.

${ }^{13}$ Laporan Perkara Pengadilan Agama Bungku Kelas II Tahun 2017.

${ }^{14}$ Undang-Undang Nomor 7 Tahun 1989, Pasal 49 Tentang Peradilan Agama.

${ }^{15}$ Ahrum Hoerudin, Pengadilan Agama (Bahasan Tentang Pengertian, Pengajuan Perkara dan Kewenangan Pengadilan Agama Setelah Berlakunya Undang-Undang No. 7 Tahun 1989 Tentang Peradilan Agama), (Bandung: Citra Aditya Bakti, 1999), h. 11.

${ }^{16}$ Binsar Siregar, Hukum Hakim dan Keadilan Tuhan, (Jakarta: Gema Insani Press, 1995), h. 34 . 
Mengenai hal ini, putusan hakim pada hakekatnya hanyalah memilih skala prioritas dari sekian banyak alternatif hukum dan akibatnya pada setiap kasus yang dhadapi. Dalam memilih skala prioritas tersebut hakim berpedoman pada asas atau kaidah hukum yang lazim dan diakui oleh ahli maupun masyarakat awam yakni memberikan berdasarkan asas hukum maslahat. ${ }^{17}$

Sebagai penyelesain perkara, putusan itu hanya mengikat atau berlaku bagi para pihak atau terhukum saja, dan terutama bagian diktumlah yang mengikat para pihak atau terhukum, baik yang deklaratif maupun yang dispositive, artinya para pihak harus mematuhi dan melaksanakan bunyi diktum $^{18}$.

Hakim sebagai penegak hukum dan keadilan wajib menggali, mengikuti, dan memahami nilai-nilai hukum yang hidup dalam masyarakat ${ }^{19}$. Hakim dalam menyelesaikan perkara yang diajukan kepadanya wajib memperhatikan dengan sungguh-sungguh nilai hukum yang hidup dalam masyarakat sehingga putusannya sesuai dengan rasa keadilan dan melaksanakan maslahat.

\section{Metodologi Penelitian}

Penelitian ini dilakukan di wilayah Pengadilan Tinggi Agama Palu yang yang dianggap sebagai kawal terdepan Mahkamah Agung yang mewilayahi pengadilan dibawahnya dan ditambah empat pengadilan tingkat pertama yakni 1 . Pengadilan Agama Donggala, 2. Pengadilan Agama Parigi, 3. Pengadilan Agama Buol dan 4. Pengadilan Agama Bungku sebagai obyek utama yang dianggap oleh peneliti sudah mewakili kewilayahan pengadilan agama yang berada diwilayah hukum Pengadilan Tinggi Agama Palu. Lokasi penelitian yang dipilih tersebut di atas dikarenakan berbagai macam faktor, diantaranya adanya kelas dari pengadilan, yakni keterwakilan kelas pengadilan dari kelas I-B dan kelas II, juga dikarenakan kultur masyarakat yang terdiri dari Suku Kaili, Suku Makassar, Suku Bugis, Suku Buton, Jawa, Bungku, Lombok, Buton, dan sebagian kecil meliputi Minangkabau, Batak dan Sunda yang merupakan etnis yang berada di wilayah Provinsi Sulawesi Tengah, wilayah tersebut yang merupakan wilayah yurisdiksi dari Pengadilan Tinggi Agama Palu.

${ }^{17}$ Mukti Arto, Penemuan Hukum Islam Demi Mewujudkan Keadilan, "Membangun Sistem Peradilan Berbasis Perlindungan Hukum dan Keadilan" (Yoqyakarta: Pustaka Pelajar, 2017), h. 226-245.

${ }^{18}$ Sudikno Mertokusumo, Penemuan Hukum, Sebuah Pengantar (Cet. IV; Yoqyakarat: Cahaya Atma Pustaka, 2014), h. 69-70. Kehakiman.

${ }^{19}$ Undang-Undang Nomor 48 Tahun 2009, Pasal 5 Ayat (1) Tentang Kekuasaan 
Penelitian ini merupakan penelitian deskriptif, dengan ini menggunakan pendekatan ${ }^{20}$ multidisipliner, ${ }^{21}$ teologis normatif, yuridis, sosiologis, dan filosofis. Sumber data yang digunakan dalam penelitian ini adalah Sumber data lapangan yaitu sumber data yang diperoleh selama penelitian di Wilayah Hukum Pengadilan Tinggi Agama Palu, yang meliputi 1. Pengadilan Agama Donggala, 2. Pengadilan Agama Parigi, 3. Pengadilan Agama Buol, 4. Pengadilan Agama Bungku, wawancara dengan hakim, terutama kepada hakim yang menjadi majelis hakim dalam penanganan perkara dispensasi kawin di pengadilan agama masing-masing.

\begin{tabular}{|c|c|c|c|}
\hline No & Pengadilan & Jumlah & Keterangan \\
\hline 1 & Pengadilan Agama Donggala & 3 orang & Majelis Hakim \\
\hline 2 & Pengadilan Agama Parigi & 3 orang & Majelis Hakim \\
\hline 3 & Pengadilan Agama Buol & 3 orang & Majelis Hakim \\
\hline 4 & Pengadilan Agama Bungku & 3 orang & Majelis Hakim \\
\hline & Jumlah & 12 orang & Majelis Hakim \\
\hline
\end{tabular}

Teknik pengumpulan data yang digunakan dalam penelitian ini adalah:

1. Telaah literatur difokuskan pada referensi yang berkenaan dengan hukum Islam tentang mediasi, kajian peraturan perundang-undangan, terutama yang berhubungan dengan dispensasi Kawin, buku-buku, yurisprudensi, penetapan hakim, jurnal, majalah, media cetak, dan dokumen-dokumen lainnya yang relevan dengan penelitian ini dan diperoleh dengan cara penelusuran arsip dari berbagai sumber.

2. Observasi adalah teknik pengumpulan data yang digunakan untuk menghimpun data penelitian melalui pengamatan dan penginderaan. ${ }^{22}$ Observasi dalam penelitian ini dilakukan pada beberapa lokasi yakni 1 . Pengadilan Agama Donggala, klas I B, 2. Pengadilan Agama Parigi, 3. Pengadilan Agama Buol, klas II, 4. Pengadilan Agama Bungku klas II.

3. Wawancara digunakan sebagai metode pengumpulan data apabila peneliti melakukan studi pendahuluan untuk menemukan permasalahan yang harus diteliti, tetapi juga apabila ingin mengetahui hal-hal dari informan

${ }^{20}$ Abuddin Nata, Metodologi Studi Islam (Cet. IX; Jakarta: Raja Grafindo Persada, 2004), h. 28 .

${ }^{21}$ Disebut multidisipliner karena menggunakan logika atau cara berpikir lebih dari satu cabang ilmu hukum. Lihat C.F.G. Sunaryati Hartono, Penelitian Hukum di Indonesia pada Akhir Abad ke-20 (Bandung: Alumni, 1994 M), h. 124.

${ }^{22}$ Burhan Bungin, Penelitian Kualitatif (Jakarta: Kencana, 2009), h. 115. 
yang lebih mendalam. ${ }^{23}$ Penelitian ini menggunakan wawancara terstruktur, semiter-struktur, ${ }^{24}$ dan wawancara kelompok ${ }^{25}$ yakni dialog oleh penulis dengan informasi yang diasumsikan mengetahui jelas tentang konsepsi pembuatan Penetapan Pengadilan yang mengimplementasikan asas maslahah.

4. Dokumentasi, dimaksud adalah metode dokumentasi dengan mempelajari dokumen tertulis seperti surat permohonan dispensasi kawin dan putusan/penetapan pengadilan agama, peraturan-peraturan, dan sebagainya. $^{26}$

Selain pedoman observasi, pedoman wawancara, pedoman dokumentasi digunakan pula instrumen tambahan berupa pedoman deskripsi murni dan opini yang memberikan gambaran nyata terhadap kondisi terkini ketika melakukan pengumpulan data baik itu pengamatan, wawancara maupun dokumentasi yang pada pokoknya memiliki relevansi tema judul penelitian ini.

Instrumen utama pada penelitian ini adalah peneliti sendiri, selain peneliti instrumen lain yang digunakan dalam penelitian adalah:

1. Buku catatan (buku tulis), buku dan alat tulis, selain buku penulis juga mempersiapkan alat tulis untuk mencatat hasil wawancara dengan para narasumber, mencatat temuan-temuan yang yang berkaitan dengan penelitian.

2. Telpon genggam (HP), dipergunakan untuk wawancara jarak jauh dengan narasumber, guna memperjelas serta mengklarifikasi hal-hal yang dianggap belum sempurna atau masih kabur.

3. Media sosial (Medsos), media sosial dimaksud adalah alat komunikasi modern dengan mengutamakan kekuatan jaringan internet, seperti aplikasi WhatApps (WA), BBM, Face Book, Twiteer dan Flashdisk, digunakan untuk mengumpulkan data-data elektronik dalam bentuk file, yang tersimpan di dalam perangkat computer atau laptop.

${ }^{23}$ Sugiyono, Memahami Penelitian Kualitatif, h. 72.

${ }^{24}$ Wawancara terstruktur digunakan sebagai teknik pengumpulan data bila peneliti atau pengumpul data mengetahui dengan pasti tentang informasi yang diperoleh, sehingga dalam melakukan wawancara, pengumpul data telah menyiapkan instrumen penelitian berupa pertanyaan-pertanyaan tertulis yang alternatif jawabannya pun telah disiapkan. Wawancara semiterstruktur termasuk dalam kategori wawancara mendalam (in-depth interview), pada pelaksanaannya lebih bebas bila dibandingkan dengan wawancara terstruktur. Tujuannya adalah untuk menemukan permasalahan secara lebih terbuka, pihak yang diwawancarai diminta pendapat dan idenya. Lihat Sugiyono, Memahami Penelitian Kualitatif, h. 73-74.

${ }^{25}$ Bentuk wawancara ini dapat diimpelementasikan dalam format wawancara struktur, wawancara tidak terstruktur atau gabungan keduanya. Model wawancara ini dilakukan dengan cara peneliti mengajukan pertanyaan yang simutlan kepada beberpa individu yang telah hadir dalam kelompok yang ditetapkan. Lihat Muhammad Idrus, Metode Penelitian Ilmu Sosial; Pendekatan Kualitatif Dan Kuantitatif, Edisi II (Jakarta: Erlangga, 2009 M), h. 108.

${ }^{26}$ Lexy J. Moleong, Metodelogi Penelitian Kualitatif (Bandung: Remaja Rosdakarya, 2009) h. 186. 
4. Kamera, kamera berfungsi untuk mengambil foto kegiatan penelitian, seperti wawancara, foto lokasi penelitian dan akan digunakan sebagai data pendukung terhadap kelengkapan penelitian disertasi ini dan Printer, digunakan untuk mencetak dokumen-dokumen dilokasi penelitian yang sekiranya tidak mungkin untuk di simpan di flashdisk dan Email, dipergunakan untuk melengkapi kekurangan data yang diperoleh peneliti selama di lokasi penelitian.

Data yang diperoleh akan dianalisis lewat analisis data kualitatif, dengan menggunakan alat analisis tematik, di mana tema-tema yang diperoleh dikelompokkan dan dianalisis berdasarkan kelompok-kelompok tema yang sudah ditentukan sejak awal penelitian. ${ }^{27}$ Analisis tersebut untuk menjawab terkait masalah-masalah yang sedang diteliti, yaitu tentang Implementasi Asas Dispensasi Kawin di Wilayah Pengadilan Tinggi Agama Palu Perspektif Maslahah.

Validitas isi ditegakkan pada langkah telaah dan revisi butir pertanyaan/butir pertanyaan, berdasarkan pendapat profesional (professional judgment) para penelaah. Pada tahap ini dilakukan pengkajian tentang kesimpulan awal yang telah diambil dengan data pembanding teori tertentu, melakukan pengecekan ulang, mulai dari pelaksanaan pra survei (orientasi), wawancara, observasi, dan dokumentasi, kemudian membuat kesimpulan umum untuk dilaporkan sebagai hasil penelitian yang telah dilakukan.

Sebagai pertanggungjawaban akademik, peneliti wajib menginformasikan secara lengkap proses penegakan validitas isi keabsahan dari sebuah penelitian termasuk data cek yang digunakan dalam proses validitas serta nama yang dijadikan informan dalam proses penelitian ini beserta kualifikasi akademik. ${ }^{28}$

\section{Hasil Penelitian dan Pembahasan}

Berdasarkan hasil penelitian tentang Implementasi Asas Dispensasi Kawin di Wilayah Hukum Pengadilan Tinggi Agama Palu perspektif Maslahah, dalam hal ini mengambil empat pengadilan sebagai obyek yakni di Pengadilan Agama Donggala Kelas II B, Pengadilan Agama Parigi Kelas II, Pengadilan Agama Buol Kelas II dan Pengadilan Agama Bungku Kelas II, selama tahun 2017, maka dapat ditemukan hasil penelitian sebagai berikut:

\section{Pengadilan Agama Donggala}

a. Dasar Hukum dan sejarah Pengadilan Agama Donggala

1. Kepres Nomor. 85 Tahun 1996 Tentang Pembentukan Pengadilan Agama Bitung, Palu, Unaaha, Bobonaro, Baucau, Malang, Cibinong, Tigaraksa Dan Pandan;

2. Keputusan Mentri Agama Nomor: 303 Tahun 1990 jo. Keputusan Mentri Agama Nomor: 250 Tahun 1997

\footnotetext{
${ }^{27}$ Rahmadi Usman, Pilihan Penyelesaian Sengketa di Luar Pengadilan (Bandung, PT. Citra Aditya Bakti, 2003), h.79.

${ }^{28}$ Sumadi Suryasubrata, Metodologi Penelitian, h.61.
} 
3. Keputusa Ketua Mahkamah Agung Nomor: 084/SK/II/1992 jo. Keputusan Ketua Mahkamah Agung Nomor: 025/SK/IV/1997.

Pengadilan Agama Donggala diresmikan pada tanggal 3 juli 1997 berdasarkan Keputusan Presiden Nomor 85 tahun 1996 adalah Pengadilan Agama yang mewilayahi Dati II Donggala yang terdiri dari 18 Kecamatan yang merupakan pemekaran dari Pengadilan Agama Palu sebagai akibat terbitnya Undang-Undang No.4 tahun 1994 tentang pembentukan Kota Madya Palu.

Pada Tanggal 23 Desember 2003 Pengadilan Agama Donggala Yang semula berkedudukan di Palu dipindahkan ke Donggala yang mewilayahi Kabupaten Donggala yang terdiri atas 21 Kecamatan dan Kabupaten Parigi Moutong yang terdiri atas 8 Kecamatan, dengan luas wilayah keseluruhan $16.703,56 \mathrm{~km}^{2}$.

\section{b. Visi dan Misi Pengadilan Agama Donggala}

Pengadilan Agama Donggala mempunyai visi Yakni "Mewujudkan Pengadilan Agama Donggala yang Bermartabat dan di Hormati untuk memperkokoh Landasan Menuju Peradilan Yang Agung” dan mepunyai Misi sebagai berikut:

1. Menjaga kemandirian Pengadilan Agama Donggala.

2. Memberikan pelayanan hukum yang prima kepada pencari keadilan.

3. Meningkatkan kwalitas sumber daya aparatur Pengadilan Agama Donggala.

4. Meningkatkan kredibilitas dan transparansi Pengadilan Agama Donggala.

\section{Tabel I}

Statistik Perkara di Pengadilan Agama Donggala Kelas 1 B Periode Tahun 2017

\begin{tabular}{|c|c|c|c|c|}
\hline No. & Jenis Perkara & $\begin{array}{c}\text { Jumlah Perkara } \\
\text { Diterima }\end{array}$ & $\begin{array}{c}\text { Perkara yang } \\
\text { Di Putus }\end{array}$ & $\begin{array}{c}\text { Sisa } \\
\text { perkara }\end{array}$ \\
\hline 1. & Cerai Gugat & 292 & 290 & 2 \\
\hline 2. & Ceari Thalak & 86 & 85 & 1 \\
\hline 3. & Harta Bersama & 3 & 3 & 0 \\
\hline 4. & PAW & 1 & 1 & 0 \\
\hline 5. & Istbat Nikah & 605 & 605 & 0 \\
\hline 6. & $\begin{array}{c}\text { Dispensasi } \\
\text { Kawin }\end{array}$ & 10 & 10 & 0 \\
\hline
\end{tabular}

Tingginya angka permohonan perkara dispensasi kawin di Pengadilan Agama Donggala yang banyak diajukan oleh pemohon dari pihak calon pria, yakni kedua orang tua, dengan rata-rata usia 15 (lima belas) tahun sampai 17 (tujuh belas) tahun. Sedangkan pihak mempelai wanita diantara rata-rata usia 14 (empat belas) tahun sampai 15 (lima belas) tahun. ${ }^{29}$

\section{Pengadilan Agama Parigi}

\section{a. Sejarah Pengadilan Agama Parigi}

Kabupaten Parigi Moutong adalah merupakan salah satu wilayah Kabupaten yang berada dibawah Wilayah pemerintahan Provinsi Sulawesi

${ }^{29}$ Rustam, Hakim Pengadilan Agama Donggala, wawancara, Donggala 15 Mei 2018 
Tengah, terletak di pesisir Teluk Tomini Provinsi Sulawesi Tengah dengan letak geografis Posisi 0 50'LS dan 120 68.2' BT. Sebelah utara berbatasan dengan Kabupaten Toli-Toli dan Provinsi Gorontalo, sebelah timur dengan teluk Tomini, sebelah selatan dengan Kabupaten Poso serta sebelah barat berbatasan dengan Kabupaten Donggala. Dengan luas wilayah 6.231,85 km2.

Sebelum dibentuknya Pengadilan Agama Parigi, masyarakat yang berada di wilayah ini mengajukan perkaranya ke Pengadilan Agama Donggala karena memang secara geografis wilayah tersebut masuk dalam yurisdiksi Pengadilan Agama Donggala. Maka atas dasar pemikiran bahwa pelayanan terhadap masyarakat khususnya di bidang pelayanan hukum sangat dibutuhkan di daerah ini, sehingga atas dasar saran dan masukan dari berbagai pihak, maka diajukanlah usulan pembentukan Pengadilan Agama Parigi ke Mahkamah Agung R.I. melalui Pengadilan Tinggi Agama Palu.

Pada tanggal 24 Februari 2011, Bapak Presiden Republik Indonesia menandatangani Kepres Nomor 3 Tahun 2011 tentang Pembentukan Pengadilan Agama Parigi beserta 15 Pengadilan Agama lainnya yang tersebar di seluruh Indonesia. Kemudian peresmian ke 16 Pengadilan Agama yang baru tersebut secara serentak oleh Bapak Ketua Mahkamah Agung R.I. (Dr. Harifin A. Tumpa, S.H. M.H.) pada tanggal 16 November 2011 di Labuan Bajo.

\section{b. Visi dan Misi Pengadilan Agama Parigi}

Pengadilan Agama Parigi mempunyai Visi "Terwujudnya Peradilan Agama Parigi yang Agung dan Bermartabat" dan mempunyai dan memiliki Misi sebagai berikut:

1. Memberikan pelayanan prima (excellence service) kepada semua stakeholder.

2. Memberikan pelayanan hukum yang berkeadilan kepada pencari keadilan.

3. Mewujudkan management peradilan modern berbasis Teknologi Informasi.

4. Meningkatkan profesionalisme dan kredibilitas Aparatur Pengadilan Agama Parigi.

5. Meningkatkan Transparansi dan Akuntabilitas guna mewujudkan good governance.

Tabel I

Statistik Perkara di Pengadilan Agama Parigi Kelas II Periode Tahun 2017

\begin{tabular}{|c|c|c|c|c|}
\hline No. & Jenis Perkara & $\begin{array}{c}\text { Jumlah Perkara } \\
\text { Diterima }\end{array}$ & $\begin{array}{c}\text { Perkara yang } \\
\text { Di Putus }\end{array}$ & $\begin{array}{c}\text { Sisa } \\
\text { perkara }\end{array}$ \\
\hline 1. & Cerai Gugat & 275 & 274 & 1 \\
\hline 2. & Ceari Thalak & 103 & 101 & 1 \\
\hline 3. & Perubahan identitas & 1 & 1 & 0 \\
\hline 4. & Perwalian & 3 & 3 & 0 \\
\hline 5 & Wali Adhol & 1 & 1 & 0 \\
\hline 6. & PAW & 1 & 1 & 0 \\
\hline 7. & Istbat & 123 & 123 & 0 \\
\hline
\end{tabular}




\begin{tabular}{|c|c|c|c|c|}
\hline 8 & Poligami & 1 & 1 & 0 \\
\hline 9 & Pengangkatan anak & 1 & 1 & 0 \\
\hline 10 & Pembatalan nikah & 1 & 1 & 0 \\
\hline 11 & Dispensasi Kawin & 24 & 24 & 0 \\
\hline
\end{tabular}

Memperhatikan data pada table tersebut, peneliti menilai perkara menunjukkan tingginya perkara yang masuk diterima dan diputuskan oleh Pengadilan Agama Parigi terutama di perkara cerai gugat dan cerai thalak serta perkara lainnya yakni istbat nikah. Sementara yang juga tinggi angka perkaranya adalah permohonan dispensasi kawin yang hanya dalam rentang waktu satu tahun, hal ini menunjukkan adanya kecendrungan meningkat setiap tahunnya.

Naiknya angka permohonan perkara dispensasi kawin di Pengadilan Agama Parigi yang diajuakn oleh para pemohon baik dari pihak calon pengantin pria dan/atau kedua orang tua calon mempelai, dengan rata-rata usia 14 ( empat belas) tahun sampai 15 (lima belas) tahun untuk wanita. Sedangkan pihak mempelai pria diantara rata-rata usia 16 (enam belas) tahun sampai 1 (tujuh belas) tahun. ${ }^{30}$

\section{Pengadilan Agama Buol}

\section{a. Sekilas Tentang Pengadilan Agama Buol}

Berdirinya Pengadilan Agama Buol pada mulanya merupakan balai sidang Pengadilan Agama Kabupaten Buol Tolitoli yaitu tempat untuk sidang keliling guna membantu masyarakat pencari keadilan yang berada di Kecamatan Biau, Kecamatan Bokat, Kecamatan Bukal, Kecamatan Momunu, dan Kecamatan Paleleh, yang berjarak antara 160 sampai $250 \mathrm{Km}$, dengan ibukota Buol Tolitoli.

Seiring dengan telah dimekarkannya Buol dari kabupaten induk menjadi Kabupaten sendiri pada tahun 1999 keberadaan Pengadilan Agama di Kabupaten tersebut sangat urgen untuk optimalisasi pelayanan dalam menyelesaikan permasalahan hukum tertentu yang menjadi kewenangan Pengadilan Agama bagi masyarakat pencari keadilan yang berada di wilayah Kabupaten tersebut.

Pada tahun 2002 Pengadilan Agama Buol secara definitif terbentuk berdasarkan Keputusan Presiden RI Nomor 62 tahun 2002 tentang pembentukan Pengadilan Agama bersama-sama dengan 12 Pengadilan Agama lain meliputi: 1. Pengadilan Agama Muaratebo 2. Pengadilan Agama Sengeti 3. Pengadilan Agama Gunung Sugi 4. Pengadilan Agama Blambangan 5. Pengadilan Agama Umpu. 6. Pengadilan Agama Depok 7. Pengadilan Agama Bontan 8. Pengadilan Agama Cilegon. 9. Pengadilan Agama Sangatta. 10. Pengadilan Agama Buol. 11. Pengadilan Agama Bungku. 12. Pengadilan Agama Banggai Kepulauan. 13.Pengadilan Agama Tilamuta . 
b. Visi dan Misi Pengadilan Agama Buol

Pengadilan Agama Buol mempunyai Terwujudnya Pengadilan Agama Buol Menuju Peradilan Agama Yang Agung dan memiliki Misi sebagai berikut:

1. Mewujudkan peradilan yang mandiri dan independen bebas dari campur tangan pihak lain.

2. Memelihara hubungan antara instansi pemerintah dan instansi vertical.

3. Memberikan pelayanan yang efektif, efisien dan berkeadilan kepada pen cari keadilan.

4. Membangun landasan yang handal dalam mewujudkan kualitas sumber daya manusia demi kelancaran tugas dan fungsi instansi.

5. Meningkatkan kwalitas kerja dan transparansi Pengadilan Agama Buol.

Tabel

Statistik Perkara di Pengadilan Agama Bungku

Periode Tahun 2017

\begin{tabular}{|c|c|c|c|c|}
\hline No. & Jenis Perkara & $\begin{array}{c}\text { Jumlah Perkara } \\
\text { Diterima }\end{array}$ & $\begin{array}{c}\text { Perkara yang } \\
\text { Di Putus }\end{array}$ & $\begin{array}{c}\text { Sisa } \\
\text { perkara }\end{array}$ \\
\hline 1. & Cerai Gugat & 143 & 149 & 15 \\
\hline 2. & Ceari Thalak & 53 & 50 & 9 \\
\hline 3. & Harta Bersama & 0 & 0 & 0 \\
\hline 4. & $\begin{array}{c}\text { Pengesahan } \\
\text { anak }\end{array}$ & 0 & 0 & 0 \\
\hline 5. & Perwalian & 0 & 0 & 0 \\
\hline 6. & Asal usul anak & 0 & 0 & 0 \\
\hline 7. & Istbat & 69 & 70 & 1 \\
\hline 8. & $\begin{array}{c}\text { Dispensasi } \\
\text { Kawin }\end{array}$ & 33 & 32 & \\
\hline
\end{tabular}

Data pada tabel tersebut, peneliti menilai perkara menunjukkan tingginya perkara yang masuk diterima dan diputuskan oleh Pengadilan Agama Parigi terutama di perkara cerai gugat dan cerai thalak serta perkara lainnya yakni istbat nikah. Sementara yang juga tinggi angka perkaranya adalah permohonan dispensasi kawin yang hanya dalam rentang waktu satu tahun, hal ini menunjukkan adanya kecendrungan meningkat setiap tahunnya.

Naiknya angka permohonan perkara dispensasi kawin di Pengadilan Agama Parigi yang diajuakn oleh para pemohon baik dari pihak calon pengantin pria dan/atau kedua orang tua calon mempelai, dengan rata-rata usia 14 (empat belas) tahun sampai 15 (lima belas) tahun untuk wanita. Sedangkan pihak mempelai pria diantara rata-rata usia 16 (enam belas) tahun sampai 1 (tujuh belas) tahun. ${ }^{31}$

${ }^{31}$ M. Jalaludin, Hakim Pengadilan Agama Buol, wawancara, Buol 15 April 2018 


\section{Pengadilan Agama Bungku}

\section{a. Sejarah Pengadilan Agama Bungku}

Kabupaten Morowali merupakan salah satu daerah otonom yang terbentuknya bersama dengan dua kabupaten lainnya di Propinsi Sulawesi Tengah berdasarkan Undang-Undang Nomor 51 Tahun 1999 tentang Pembentukan Kabupaten Morowali, dan Kabupaten Banggai Kepulauan.

Pengadilan Agama Bungku dibentuk berdasarkan Keputusan Presiden Republik Indonesia Nomor 62 Tahun 2002 tanggal 28 Agustus 2002, yang kemudian diresmikan pada tanggal 18 Maret 2003 oleh Dirjen Bimas Islam dan Penyelenggaraan Haji di Palu Sulawesi Tengah. Pengadilan Agama Bungku merupakan salah satu dari Sembilan lembaga peradilan Agama yang ada di Sulawesi Tengah yang berada di wilayah yuridiksi Pengadilan Tinggi Agama Sulawesi Tengah.

Berdasarkan Peraturan Pemerintah No.45 tahun1957 pada Pasal (berbunyi: Di tempat-tempat yang ada Pengadilan Negeri ada sebuah Pengadilan Agama/ MahkamahSyariyah, yang daerah hukumnya sama dengan daerah hokum Pengadilan Negeri.) dan Penetapan Menteri Agama No. 5 Tahun 1958 sebagai Realisasi PP No. 45 tahun 1957.

\section{b. Visi dan Misi Pengadilan Agama Bungku}

Pengadilan Agama Bungku mempunyai Visi "Mendukung Terwujudnya Badan Peradilan Agama Yang Agung Pada Pengadilan Agama Bungku." Dan mempunyai Misi sebagai berikut:

1. Mewujudkan peradilan agama yang sederhana, tepat waktu, biaya ringan dan transparan

2. Melaksanan tertib administrasi dan manajemen peradilan yang efektif dan efisien

3. Melaksanakan pengawasan dan pembinaan secara efektif dan efisien

4. Mengupayakan tersedianya sarana dan prasarana peradilan agama berbasis teknologi informasi.

Tabel

Statistik Perkara Pengadilan Agama Bungku Periode Tahun 2017

\begin{tabular}{|c|c|c|c|c|}
\hline No. & Jenis Perkara & $\begin{array}{c}\text { Jumlah } \\
\text { Perkara } \\
\text { Diterima }\end{array}$ & $\begin{array}{c}\text { Perkara yang } \\
\text { Di Putus }\end{array}$ & $\begin{array}{c}\text { Sisa } \\
\text { perkara }\end{array}$ \\
\hline 1. & Cerai Gugat & 165 & 7 & 0 \\
\hline 2. & Ceari Thalak & 117 & 12 & 0 \\
\hline 3. & Harta Bersama & 1 & 1 & 0 \\
\hline 4. & Pengesahan anak & 1 & 1 & 0 \\
\hline 5. & Perwalian & 2 & 2 & 0 \\
\hline 6. & Asal usul anak & 5 & 5 & 0 \\
\hline 7. & Istbat & 247 & 247 & 0 \\
\hline 8. & Dispensasi Kawin & 17 & 17 & \\
\hline
\end{tabular}


Tingginya jumlah perkara permohonan Dispensasi Kawin di Pengadilan Agama Bungku yang diajuakn oleh para pemohon baik dari pihak calon pengantin pria dan/atau kedua orang tua calon mempelai, ada pada nilai rata-rata pada usia 14 ( empat belas) tahun sampai 15 (lima belas) tahun untuk calon wanita sedangkan pihak mempelai pria diantara rata-rata usia 17 (tujuh belas) tahun.$^{32}$

\section{Sebab-Sebab Dispensasi Kawin}

Batas usia dalam perkawinan terkait dengan kematangan sosial suami isteri, dengan maksud bahwa tanggung jawab sosial suami isteri dalam batas usia tersebut dapat terselenggara dengan baik di dalam membina kesejahteraan keluarga dan pergaulan bermasyarakat.

Ada beberapa faktor diajukannya permohonan dispensasi kawin kepangadilan yakni sebagai berikut:

\section{a) Hamil}

Dispensasi Kawin yang diajukan permohonan ke Pengadilan Agama adanya pergaulan bebas yang dilakukan kedua anak yang masih dibawah umur sehingga salah satu penyebabnya adalah karena calon wanitanya sedang mengandung/hamil.

Calon mempelai laki-laki dan calon mempelai permpuan dalam kesehariannya rata-rata masih berstat us siswa, baik ditingkat SMA sederajat dan SMP Sederajat namun karena telah melakuan hubungan badan bersama pacarnya lalu kemudian mengalami kehamilan maka mereka memutuskan untuk berhenti melanjutkan pendidikannya.

Alasan hamil dalam pengajuan permohonan Dispensasi kawin kepengadilan menjadi urutan pertama, baik yang diajukan oleh pihak laki-laki maupun yang diajukan permohonan Dispensai Kawin tersebut oleh perempuan dan biasanya usia kandungan sudah diantara dua bulan sampai enam bulan. ${ }^{33}$

\section{b) Kekhawatiran/Ketakutan}

Semangkin majunya perkembangan teknologi, juga menuntut kemajuan dibidang lain, seperti hiburan dan cara pergaulan para anak muda dimasa kini yang tentunya menjadi perhatian dari pada banyak orang tua. Melihat pertumbuhan anak yang sulit diprediksi dan pertemanannya yang tidak mudah di awasi tentu akan menimbulkan kekhawatiran.

Rasa khawatir terhadap keadaan anak dalam menjalani pertemanan dan membangun komunikasi dengan teman-temannya terutama dengan teman lakilakinya menjadi persoalan tersendiri yang perlu diatasi, ditambah seringnya anak tanpa memperhatikan ruang dan waktu dalam pergaulan sehingga hal yang untuk masa depan anak terabaikan.

Munculnya rasa kekhawatiran dan ketakutan pada orang tua terhadap perkembangan anaknya, terutama yang mempunyai anak perempuan tentang kehidupan dalam pergaulan dengan teman-teman sebayanya tentu akan

\footnotetext{
${ }^{32}$ Andi Fachrurrazi K.L, Hakim Pengadilan Agama Bungku, wawancara, Bungku 10 April 2018

${ }^{33}$ Rustam, Hakim Pengadilan Agama Donggala, Wawancara, Donggala pada tanggal 14 Mei 2018.
} 
membawanya pada situasi kehidupan yang berbeda yang mengrah pada yang negative sehingga tidak jarang akan jatuh pada pergaulan bebas jika hal tersebut betul-betul lepas dari control orang tua.

Keadaan ini tentunya akan menjadi masalah tersendiri dikalangan orang tua sehingga untuk mengakhiri gerak dan langkah anak yang menimbulkan kekhawatiran orang tua akan terjadinya hal-hal yang tidak diinginkan maka perKawinan pada usia dini seolah menjadi penangkal yang baik yang tidak mampu utuk di hindari.

\section{c) Ekonomi}

Selain dari pada pergaulan bebas dalam hal ini sudah terjadinya kehamilan pada pihak perempuan dan adanya rasa kekhawatiran yang mendalam, juga yang tidak jarang menjadi persoalan/faktor terjadinya perKawinan dini adalah masalah ekonomi.

Mempunyai latar belakang keadaan ekonomi yang rendah. Hal ini bisa mendorong untuk melakukan perkawinan usia muda dengan tujuan dan harapan bahwa dengan terjadinya perkawinan akan mengurangi beban ekonomi keluarga yang dinilai kurang mampu.

Situasi keadaan orang tua yang tidak mampu, pekerjaan yang serabutan dan pendapatan yang tidak menentu sehingga dalam memberikan nafkah dalam memenuhi kebutuhan sehari-hari terasa sulit karena keadaan ekonomi yang tidak mampu dan kebutuhan yang tinggi sehingga mengakibatkan untuk meKawinkan anak-anaknya pada usia dini demi untuk mengurangi beban keluarga.

\section{d) Budaya}

Kuatnya budaya menjadikan salah satu penyebab terjadinya Kawin dini. katagori perKawinan dini. Pada tahun 2008 dari dua juta lebih pasangan yang meKawin dibawah usia 16 (enam belas) tahun mencapai 35 persen

Fenomena Kawin di usia muda sudah banyak ditemukan di Indonesia. Kendati banyak ditentang kebiasaan kawin muda masih banyak terjadi dibeberapa daerah yang dikenal dengan kebiasaan awin muda. Ada daerah yang anak gadisnya kawin rata-rata diusia 14-15 tahun, bahkan ada yang kawin setelah hari pertama mengalami menstruasi yang mana hal ini disampaikan dalam wawancara dengan bapak Amar Ma'ruf, hakim Pengadilan Donggala.

Berdasarkan penelitian di wilayah hukum Pengadilan Tinggi Agama Palu, yakni pengadilan yang dijadikan tempat mendapatkan data tentang terjadinya dispensasi kawin yakni Pengadilan Agama Donggala, Pengadilan Agama Parigi, Pengadilan Agama Buol dan Pengadilan Agama Bungku mengindikasikan bahwa kawin muda karena adanya budaya dikalangan keluarga tersebut untuk segera menikahkan anaknya meskipun masih dalam usia yang muda.

Pertimbangan yang sangat mencolok dan sangat sering dipergunakan pengadilan agama dalam pertimbangan untuk mengabulkan yakni demi kemaslahatan dan keadilan social (social justice), bahwa dengan keadaan seperti tersebut tentunya suatu hal yang mustahil untuk dibiarkan tanpa adanya alas 
pijakan yang benar secara hukum, yang penting juga adalah kaitannya dengan kedudukannya ditengah masyarakat.

\section{e) Perjodohan}

Pada praktiknya yang di dahului dengan pertunangan antara laki-laki dan perempuan dari kedua belah pihak yang dilakukan pada usia yang masih muda karena kebanyakan dalam hal pertunangan tanpa minta persetujuan anak laki-laki amaupun perempuan yang masih mempunyai hubungan kekerabatan, praktik ini biasa dilakukan untuk menjaga hubungan keluarga dan agar tali kekeluargaan tetap ada yang dalam hukum adat dikenal dengan endogamy dimana suatu perkawinan seseorang hanya dapat/diperbolehkan kawin dengan seseorang yang berasal dari suku keluarga sendiri.

Kebanyakan masyarakat yang masih menganut sistem endogamy dalam praktik perkawinan dengan dalil untuk mempertahankan perkawinan dari keluarga sendiri yang masih mempunyai hubungan kekeluargaan, namun juga ada yang mempraktikkan perkawinan dengan di luar suku sendiri yang disebut dengan eleutherogami, hal ini terjadi pada orang yang tingkat pendidikan yang sudah tinggi dan orang yang ada di perkotaan tetapi tidak menutup kemungkinan orang perkotaan juga masih kawin dengan sesama suku, karena pada dasarnya perkawinan seseorang menganut sistem endogamy.

\section{Pertimbangan Hakim Pada Dispensasi Kawin.}

Kalau dilihat setiap perkara permohonan dispensasi kawin dikarenakan beberapa faktor yang diajukan permohonan oleh para Pemohon ke Penagdilan Agama Bungku seperti calon mempelai wanita sudah mengalami kehamilan dan ini yang menjadi faktor paling banyak terjadi diajukannya permohoan dispensasi kawin karena calon mempelai wanita telah hamil, sedangkan diantara mereka sangat akrab sehingga bila dibiarkan akan menimbulkan hal-hal yang tidak diinginkan oleh orang tua.

Sebagai hakim yang sudah bertugas selama 3 (tiga) tahun 7 (tujuh) bulan sudah, sekarang bertugas di Pengadilan Agama Bungku, dalam melihat dispensasi kawin ini, saya pikir ini tergantung pada kasusunya, pada dasarnya anak dibawah umur masih belum layak membangun rumah tangga namun karena kondisi darurat dengan pertimbangan menghindari mudharat yang lebih besar sehingga mengenai permohonan dispensasi kawin akan dikabulkan.

Pada Undang-Undang Nomor 1 Tahun 1974, Tentang Perkawinan jo Imtruksi Presiden Nomor 1 Tahun 1991 Tentang Kompilasi Hukum Islam Pasal 39, demi menghindari kemadharatan yang lebih besar maka akan dijadikan rujukan dalam mengabulkan dispensasi kawin, apalagi sikap orang tua yang tidak keberatan anaknya menikah dibawah umur.

Pada Undang-Undang Nomor 1 Tahun 1974, Tentang Perkawinan, yang membatasi usia minimal untuk melakukan perkawinan yakni usia 19 tahun bagi calon pengantin pria dan 16 tahun bagi calon wanita, memang sudah benar dan sesuai dan sepakat dengan adanya hal yang menyangkut tentang dispensasi kawin. 
Menyikapi tingginya angka permohonan dispensasi kawin karena faktor pergaulan bebas menjadi salah satu sebab dispensasi kawin, kurangnya pendidikan orang tua sehingga tidak berfikir untuk menyekolahkan anaknya namun segera menikahkan sekalipun usianya masih belum cukup seperti yang disyaratkan oleh undang-undang nomor 1 tahun 1974, pasal 7 ayat (1) dan (2) Tentang Perkawinan.

Melihat perkembangan peningkatan pernikahan dini maka perlu sosialisasi peran BP4 (Badan Penasehatan Pembinaan dan Pelestarian Pernikahan) yang merupakan organisasi yang bersifat keagamaan sebagai mitra kementrian agama dan instansi terkait lain dalam upaya meningkatkan kualitas perkawinan umat Islam untuk membina dan menganyomi keluarga perlu diperkuat perannya sehingga mampu memberikan penjelasan yang utuh tentang hidup berumahtangga dan beban tanggungjawab yang besar dan resiko kehamilan diusia muda sehingga akan mampu menekan angka perceraian.

Disisi lain mengenai keberadaan Undang-Undang Nomor 1 tahun 1974 Pasal 7 ayat (1) dan (2) Tentang perkawinan belum perlu diakan revisi karena menurut saya ini sudah relevan namun melihat hal-hal yang mana lebih dikedepankan untuk kebaikan anak dan menghindari suatu madharat yang lebih besar, maka demi kepastian hukum, kemaslahatan dan ketertiban bagi masyarat yang membutuhkan perlindungan maka perkara dispensasi kawin dapat dikabulkan. ${ }^{34}$

Mayoritas perkara permohonan dipensasi kawin yang diajukan ke Pengadilan Agama Buol, yang diterima dan diperiksa, disidangkan dan diputuskan dengan pertimbangan dari berbagai macam dalil-dalil, baik yang bersifat undang-undang, peraturan pemerintah, kompilasi hukum islam, dan dalil materi berupa ayat al'quran dan hadis serta kaidah fiqh yang relevan dengan perkara tersebut, selalu dijadikan rujukan untuk mempertimbangkan berbagai bukti yang diajukan oleh para Pemohon.

Disisi lain juga melihat hal-hal yang mana lebih dikedepankan untuk kebaikan anak dan menghindari suatu madharat yang lebih besar, maka demi kepastian hukum, kemaslahatan dan ketertiban bagi masyarat yang membutuhkan perlindungan maka perkara dispensasi kawin dikabulkan. ${ }^{35}$

Sebagai hakim yang sudah bertugas selama 4 (empat) 8 (delapan) tahun dan sudah beberapa kali mutasi hingga sekarang berada di Pengadilan Agama Parigi, dalam melihat dispensasi kawin ini, saya pikir banyak aspek yang membuatnya belum siap membangun rumah tangga, karena faktor ekonomi yang belum terencana dengan baik, kematangan psikologis yang berakibat terjadinya perceraian, apalagi pendidikan anak tersebut belum selesai namun anak-anak sudah dihadapkan pada masalah perkawinan yang dimohonkan melalui dispensasi kawin.

${ }^{34}$ Dwi Reski Wahyuni, Hakim Pengadilan Bungku, Wawancara, Bungku Tanggal 10 April 2018

\footnotetext{
${ }^{35}$ Fatur Rahman, Hakim Pengadilan Agama Buol, Wawancara, Buol Tanggal 15 April
} 
Pada Undang-Undang Nomor 1 Tahun 1974, Tentang Perkawinan, yang membatasi usia minimal untuk melakukan perkawinan yakni usia 19 tahun bagi calon pengantin pria dan 16 tahun bagi calon wanita, perlu lagi diaadakan revisi, namun revisi tersbut hanya menyangkut pada persoalan usia wanita dinaikkan menjadi 18 (delapan belas) tahun, dengan usia tersebut diharapakan minimal dapat menyelesaikan pendidikannya terlebih daluhu baru kemudian diperbolehkan untuk kawin, sementara usia pria tidak perlu lagi diadakan revisi.

Mayoritas perkara permohonan dipensasi kawin yang diajukan ke Pengadilan Agama Parigi, yang diterima dan diperiksa, disidangkan dan diputuskan dengan pertimbangan dari berbagai macam dalil-dalil, baik yang bersifat undang-undang, peraturan pemerintah, kompilasi hukum islam, dan dalil materi berupa ayat al'quran dan hadis serta kaidah fiqh yang relevan dengan perkara tersebut, selalu dijadikan rujukan untuk mempertimbangkan berbagai bukti yang diajukan oleh para Pemohon yang mengedepankan perspektif maslahah

Disisi lain juga melihat hal-hal yang mana lebih dikedepankan untuk kebaikan anak dan menghindari suatu madharat yang lebih besar, maka demi kepastian hukum, kemaslahatan dan ketertiban bagi masyarat yang membutuhkan perlindungan maka perkara dispensasi kawin dikabulkan. ${ }^{36}$

Sikap dan perasaan orang tua dalam melihat persoalan dispensasi kawin yang diajukan ke pengadilan, terhadap anak-anak yang telah mengalami kehamilan, pada dasarnya mempunyai tekanan bhatin dan rasa malu yang tak terhingga namun hal itu harus dihadapi dan diselesaikan demi kebaikan dan masa depan buat anak-anak.

Sebagai hakim yang sudah bertugas selama 7 (tujuh) tahun 8 (delapan) bulan dan telah 3 (tiga) kali mengalami mutasi hingga sekarang berada di Pengadilan Agama Donggala, dalam melihat dispensasi kawin ini, saya pikir ini sudah merupakan sebuah solusi diluar perkawinan yang normal pada batas usia minimal sesuai yang diperintahkan undang-undang.

Sementara Undang-Undang Nomor 1 Tahun 1974, Tentang Perkawinan, yang membatasi usia minimal untuk melakukan perkawinan yakni usia 19 tahun bagi calon pengantin pria dan 16 tahun bagi calon wanita, tidak perlu lagi diaadakan revisi namun yang lebih penting dalam hal ini adalah bagaimana memperkuat steakholder terkait untuk memberikan pemahaman dan bimbingan mengenai usia nikah dan berbagai akibatnya. ${ }^{37}$

Mayoritas perkara permohonan dipensasi kawin yang diajukan ke Pengadilan Agama Donggala, yang diterima dan diperiksa, disidangkan dan diputuskan dengan pertimbangan dari berbagai macam dalil-dalil, baik yang bersifat undang-undang, peraturan pemerintah, kompilasi hukum islam, dan dalil materi berupa ayat al'quran dan hadis serta kaidah fiqh yang relevan dengan

${ }^{36}$ Nor Hasanuddin, Hakim Pengadilan Agama Parigi, Wawancara, Parigi Tanggal 07 Mei 2018

${ }^{37}$ Amar Ma'ruf, Hakim Pengadilan Agama Donggala, Wawancara, Donggala tanggal 14 Mei 2018. 
perkara tersebut, selalu dijadikan rujukan untuk mempertimbangkan berbagai bukti yang diajukan oleh para Pemohon.

Disisi lain juga melihat hal-hal yang mana lebih dikedepankan untuk kebaikan anak dan menghindari suatu madharat yang lebih besar, maka demi kepastian hukum, kemaslahatan dan ketertiban bagi masyarat yang membutuhkan perlindungan maka perkara dispensasi kawin dikabulkan. ${ }^{38}$

\section{Dampak Sosial Penetapan}

Hakim selaku penyelenggara Negara di bidang yudikatif secara yuridis dan konstitusional wajib memberikan perlindungan hukum dan keadilan melalui putusan/penetapannya kepada pencari keadilan secara proporsional sesuai dengan kebutuhannya baik dari aspek fisical custady maupun legal custady.

Pada keadaan tersebut maka hakim secara ex offecio wajib memberikan perlindungan hukum dan keadilan. Tanggungjawab ini merupakan kewajiban konstitusional yang pelaksanaannya secara terperinci dan jelas telah diatur oleh undang-undang.

Putusan/penetapan hakim pada hakekatnya hanyalah memilih skala prioritas dari sekian banyak alternatif fakta hukum dan akibatnya pada setiap kasus yang dihadapi. Dalam pemilihan skala prioritas tersebut hakim berpedoman pada asas atau kaidah hukum yang lazim dan diakui oleh ahli hukum maupun masyarakat sehingga putusan/penetapan tersebut memiliki dampak social bagi pihak yang berperkara.

Pada penelitian dilapangan pada perkara dispensasi kawin diwilayah hukum Penagadilan tinggi Agama Palu yang dilakukan di Pengadilan Agama Donggala, Pengadilan Agama Parigi, Pengadilan Agama Buol dan Pengadilan Agama Bungku ditemukan bahwa hasil produk hukum yang berupa penetapan pada umumnya diterima oleh para pemohon.

Bagi para pemohon yang pengajuan perkara permohonan dispensai kawin yang ditolak oleh pengadilan yakni hakim yang memeriksa perkara tersebut, belum ada yang mengajukan keberatan yakni melakukan tindakan diluar hukum berupa tindakan anarkis yang mengakibatkan ketegangan fisik antara pemohon dengan pihak pengadilan, maupun tindakan hukum berupa kasasi ke Mahkamah Agung.

Para pemohon yang mengajukan permohonan pada pengadilan dalam perkara dispensasi kawin yang dikabulkan merasa terpuaskan dan terpenuhi permohonannya sehingga memberikan jalan untuk melanjutkan urusannya yang terkait dengan anaknya yang terhambat untuk melakukan perkawinan karena melanggar batas minimal usia perkawinan yang diperintahkan undang-undang dapat diatasi selanjutnya bisa menikahkan anaknya di kantor urusan agama dimana pemohon bertempat tinggal.

Permohonan para pemohon yang dikabulkan maka akan mengahsilkan produk hukum berupa penetapan. Hasil penetapan tersebut selanjutnya akan diserahkan kepada Kantor Urusan Agama agar memproses hajat para pemohon

\footnotetext{
${ }^{38}$ Ruhana Farid, Hakim Pengadilan Agama Donggala, Wawancara, Donggala Tanggal
} 15 Mei 2018 
untuk menikahkan anaknya yang awalnya ditolak untuk diijinkan menikahkan kedua calon mempelai yang sempat tertunda.

Pada penelitian ini di Pengadilan Agama Donggala, Pengadilan Agama Parigi, Pengadilan Agama Buol dan Pengadilan Agama Bungku tidak menemukan adanya pihak-pihak terkait yang merasa keberatan atas dikabulkannya/ditolak permohonan para pemohon dalam perkara dispensasi kawin dengan melakukan penghalangan dan ancaman untuk menghambat atau membatalkan rencana pernikahan, baik kepada kedua orang tua mempelai maupun kepada kedua calon mempelai tersebut.

Dengan demikian bahwa segala proses yang dilalui dan produk hukum yang dihasilkan oleh pengadilan melalui majelis hakim yang memeriksa perkara dispensasi kawin tersebut telah mampu memberikan rasa keadilan dan kemanfaatan hukum serta ketertiban bagi masyarakat, sehingga tujuan asas hukum dalam hal ini telah tercapai.

\section{Implementasi Asas Maslahah}

Undang-Undang Nomor 1 tahun 1974 Pasal 7 Ayat (1) dan (2) Tentang Perkawinan yang dijadikan rujukan awal dalam memeriksa dan mengadili serta memutus perkara implementasi asas dispensasi kawin di wilayah hukum pengadilan tinggi agama perspektif maslahah dalam pelaksanaannya tersebut telah efektif dan maksimal.

Penelitian ini selain melihat pada penerapan Undang-Undang Nomor 1 Tahun 1974, Tentang Perkawinan pada penerapan secara formil tentang penerapan pasal-pasal yang dijadikan rujukan dalam memproses permohonan pemohon dalam perkara dispensasi kawin bahwa selain dapat mengimplementasikan asas-asas maslahah, juga dapat memberikan pastian hukum bagi masyarakat pencari keadilan.

Dilihat dari setiap permohonan dispensasi kawin yang diajukan ke pengadilan masih dalam usia yang sangat rendah/minim yakni masih di usia ratarata $16-17$ tahun bagi pria dan antara usia 14-15 tahun pada wanita.

Dari pertimbangan yang dituangkan para hakim dalam penetapan dispensasi kawin dengan melalui beberapa tahap pemeriksaan dalam buktian maka hampir semua perkara permohonan dispensasi kawin yang dimohonkan oleh para pemohon selalu dikabulkan yang mengedepankan perspektif maslahah.

Konsepsi kemaslahatan dimaksud adalah pemeliharaan terhadap maksud (tujuan) hukum yang terdiri dari lima hal, yakni pemeliharaan agama, jiwa, akal, keturunan dan harta. Setiap sesuatu yang dapat menjamin pemeliharaan lima prinsip itu merupakan maslahah dan begitu pula setiap sesuatu melalaikan lima prinsip itu merupakan mafsadah dan menolaknya merupakan maslahah.

Berdasarkan sudut pandang kekuatan atau skala prioritas (min haith quwwah fí dhatiha), maslahat terdiri dari:

a. Al-Darüriyyat (primer/essensial)

Yaitu kebutuhan yang selalu dalam kebutuhan manusia. Apabila kebutuhan tersebut tidak terpenuhi, maka rusaklah seluruh tatanan hidup manusia di dunia dan atau akhirat. Ikhtilāl (kerusakan) daruriyyat 
mengakibatkan ikhtilāl masāliḥ yang lain secara menyeluruh. Kemaslahatan daruriyyat hanya dapat diraih jika mampu mencegah segala potensi yang merusak perlindungan terhadap kemaslahatan Agama, Jiwa, Keturunan/Kehormatan, Akal dan Harta.

b. Al-Hajiyyāt (sekunder)

Yaitu kebutuhan yang tidak bersifat essensial, akan tetapi dibutuhkan untuk merealisasikan maslahah secara general. Apabila hajiyyat tidak terpenuhi, tidak mengakibatkan ikhtilāl tatanan hidup manusia sebagaimana daruriyyat tetapi akan kehilangan keleluasaan yang menimbulkan kesulitan dan keterampilan bagi manusia. Ikhtiläl hajiyyat tidak mengakibatkan ikhtilāl daruriyyat, misalnya adalah perlu adanya rukhsah (konsensi/perkenan hukum) ketika 'Azimah (regularitas) sulit dikerjakan seperti menggabung dan meringkas sholat, serta berbuka puasa ramadhan bagi musafir.

c. Al-Tahsiniyyat / Tazniyyat / Takmiliyyat (tersier)

Yaitu kebutuhan yang mengadopsi apa yang sesuai dengan praktek (adat) yang baik untuk menghindari cara-cara yang tidak disukai akal orang bijak, tipe mașlahah ini mencakup kebiasaan-kebiasaan terpuji (etik/moralitas). Ikhtilāl tahsiniyyat tidak mengakibatkan ikhtilāl daruriyyat atau hajiyyat. Contohnya dalam hal ibadah adalah taharah (kesucian) atau kesopanan tertentu dalam menutup bagian tubuh tertentu, dan dalam adat adalah etika ketika makan dan minum.

Kemaslahatan yang diperoleh bagi masyarakat pencari keadilan yang mengajukan permohonan dispensasi kawin kepengadilan agama dimana para pihak bertempat tinggal untuk anak para pemohon yang akan melakukan pernikahan terhambat oleh batas usia minimal untuk menikah seperti yang syaratkan oleh hukum positif sebagaimana ketentuan Undang-Undang Nomor 1 Tahun 1974 pasal 7 ayat (1) dan (2) Tentang perkawinan yaitu batas usia 19 tahun bagi pria dan 16 bagi wanita.

Pengadilan Agama tersebut setelah memeriksa dan mengadili tentang perkara dispensasi kawin yang disebabkan calon mempelai wanita yang telah mengandung sudah cukup alasan yang kuat bagi majelis hakim dalam pertimbangannya maka demi kebaikan dan masa depan anak-anak tersebut sehingga demi penegakan hukum dan kemaslahatan bagi permohonan para pemohon dapat dikabulkan sehingga hal demikian merupakan suatu maslahat yang bersifat darüriyyat (primer / essensial).

Kaitannya dalam perkara dispensasi kawin dengan keadilan adalah bahwa keadilan merupakan bagian dari tujuan hukum dan tujuan hukum merupakan muara akhir terhadap proses penyelesaian perkara, di antara teori tujuan hukum yang berlaku di lingkungan peradilan agama adalah keadilan (gerachtgkeit), kemanfaatan (zwegkmassigkeit) dan kepastian hukum (rechtsicherheit). Ketiga hal tersebut, idealnya harus diperhatikan secara berimbang dan professional, meskipun dalam pelaksanaannya sulit untuk diwujudkan. Sehingga keadilan harus ditekankan guna memenuhi kebutuhan hukum masyarakat pencari keadilan. 
Mengenai konsep asas keadilan, berarti hakim harus mempertimbangkan hukum yang hidup dan berkembang dalam masyarakat (living law), yang terdiri atas kebiasaan dan ketentuan hukum yang tidak tertulis. Dalam hal ini harus dibedakan rasa keadilan menurut individu, kelompok dan masyarakat. Selain itu keadilan dari suatu masyarakat tertentu, belum tentu sama dengan rasa keadilan masyarakat yang lainnya. Jadi dalam mempertimbangkan putusannya, seorang hakim harus mampu menggambarkan hal itu semua secara komprehensif dalam putusannya.

Mengenai aspek yuridis merupakan aspek yang pertama dan utama dalam putusan hakim dalam hal ini hakim yang pertama harus berpatokan kepada peraturan perundang-undangan yang berlaku. Hakim harus memahami undangundang dengan mencari undang-undang yang berkaitan dengan perkara yang sedang dihadapi. Hakim harus menilai apakah undang-undang tersebut adil, ada kemanfaatannya atau memberikan kepastian hukum jika ditegakkan, sebab salah satu tujuan hukum itu unsurnya adalah menciptakan keadilan dan ketertiban pada masyarakat.

Menjalankan tugas dan kewenangan seorang hakim mampu membuat kerangka fikir dalam menegakkan kebenaran dan keadilan, dengan berpegang pada hukum, undang-undang, dan nilai-nilai keadilan yang berkembang ditengahtengah masyarakat. Dalam diri seorang hakim yang telah mengemban sebuah amanah agar peraturan perundang-undangan diterapkan secara benar dan adil, dan apabila penerapan peraturan perundang-undangan akan menimbulkan ketidakadilan, maka hakim wajib berpihak pada keadilan (moral justice) dan mengenyampingkan hukum atau perundang-undangan (legal justice).

Hukum yang baik adalah hukum yang sesuai dengan hukum yang hidup dalam masyarakat (the living law) yang tentunya sesuai pula atau merupakan pencerminan dari nilai-nilai yang berlaku dalam masyarakat (social juctice). Keadilan yang dimaksud disini, bukanlah keadilan prosedural (formil), namun harus mencari untuk menciptakan keadilan substantif (materiil) yang sesuai dengan hati nurani hakim.

Pada hakikatnya keadilan adalah memiliki suatu tujuan yakni untuk memberikan kemanfaatan atau kebahagiaan yang sebenarnya pada sebanyak masyarakat, negara dan hukum semata-mata ada hanya untuk manfaat sejati, yaitu kebahagiaan mayoritas masyarakat, hukum itu haruslah menciptakan suatu masyarakat yang humanis, yaitu masyarakat yang memperbesar kebahagiaan bagi mayoritas masyarakat (the greatest happiness of the greatest number people).

\section{Kesimpulan}

Tingginya angka permohonan dispensasi kawin yang diajukan oleh para pemohon di wilayah hukum Pengadilan Tinggi Agama Palu, terutama di Pengadilan Agama Donggala, Pengadilan Agama Parigi, Pengadilan Agama Buol dan Pengadilan Agama Bungku, menyangkut keberadaan Undang-Undang Nomor 1 Tahun 1974, Pasal 7 aya (1) dan (2), Tentang perkawinan, Lembaran 
Negara tahun 1974 Nomor 1, yang menyatakan bahwa ayat (1) Perkawinan hanya diizinkan bila pihak pria mencapai umur 19 (sembilan belas) tahun dan pihak wanita sudah mencapai usia 16 (enam belas) tahun dan ayat (2) Dalam hal penyimpangan dalam ayat (1) pasal ini dapat minta dispensasi kepada Pengadilan atau pejabat lain yang diminta oleh kedua orang tua pihak pria atau pihak wanita.

Pengajuan dispensasi kawin oleh para pemohon kemudian diperiksa dan di adili oleh Pengadilan Agama maka ditemukan beberapa penyebab dispensasi kawin yakni 1. Calon mempelai wanita telah hamil sekitar 2 sampai 6 bulan, 2 . Adanya kekhawatiran pihak orang tua terhadap sikap dan prilaku anaknya dalam pergaulan sehari-hari yang diluar batas kewajaran sehingga mendorong orang tua untuk menikahkan anak-anaknya. 3. Budaya masih menjadi pendukung dalam persoalan nikah di usia dini. 4. Alasan akan menambah tali silaturrahmi atau memperkuat kekerabatan dan pertemanan maka perkawinan dini karena perjodohan tidak jarang akan terjadi.

Melihat fenomina dispensasi kawain yang banyak diajukan di wilayah hukum Pengadilan Tinggi Agama Palu, terutama di Pengadialan Agama Donggala, Pengadilan Agama Parigi, Pengadilan Agama Buol dan Pengadilan Agama Bungku, menyangkut keberadaan Undang-Undang Nomor 1 Tahun 1974, Pasal 7 aya (1) dan (2), Tentang perkawinan, Lembaran Negara tahun 1974 Nomor 1, yang menyatakan bahwa ayat (1) Perkawinan hanya diizinkan bila pihak pria mencapai umur 19 (sembilan belas) tahun dan pihak wanita sudah mencapai usia 16 (enam belas) tahun diperiksas dan diadili.

Demi melihat pada keadaan, kebaikan dan masa depan anak yang lebih baik maka akan menjadi pertimbangan majelis hakim. Hakim sebagai perwujudan dari Negara atau pemimpin dalam melaksanakan kewajiban dibidang penegakan hukum harus memberikan konsep penegakan hukum yang mengedapankan bahwa menghindari kemudharatan lebih baik dari pada mengedepankan kemaslahatan. Pada penanganan perkara dispensasi kawin yang dimohonkan oleh para pemohon, yakni hakim harus mampu dan berani melakukan penemuan dalam pembaharuan hukum Islam demi tetap tegaknya keadilan yang berdasarkan Ketuhanan Yang Maha Esa. Hakim dalam menangani perkara dispensasi kawin maka demi tegaknya kembali fungsi hukum Islam, yakni yang berfungsi memberikan perlindungan hukum dan keadilan kepada ummat manuasia secara konkrit demi terwujudnya maqasid al-syar'yah yang memberikan kemaslahatan. 


\section{DAFTAR PUSTAKA}

Isjwara, F., Pengantar Ilmu Politik, Jakarta, Bina Cipta.

Enseklopedia Pengetahuan Al-Qur'an dan Hadis, (Jakarta: Kamil Pustaka, 2013).

Intruksi Presiden Nomor 1 Tahun 1991, Pasal 15 Ayat (1) dan (2) Tentang Kompilasi Hukum Islam.

Moleong, Lexy J., Metodelogi Penelitian Kualitatif, Bandung: Remaja Rosdakarya, 2009.

Muhadjir, Noeng, Metode Penelitian Kualitatif, Cet. IV; Yogyakarta: Rake Sarsin, $1992 \mathrm{M}$.

Nata, Abuddin, Metodologi Studi Islam, Cet. IX; Jakarta: Raja Grafindo Persada, 2004.

Rasyid, Harun, Metode Penelitian Kualitatif Bidang Ilmu Sosial dan Agama, Pontianak: t.p., 2000.

Sabiq, Sayyid, Fiqh Sunnah, Cakrawala Publising, 2008.

Salim HS dan Erlies Nurbani, Penerapan Teori Hukum pada Penelitian Tesis dan Disertasi, Cet. II: Jakarta: Rajawali Pers, 2013.

Santoso, Agus, Hukum, Moral dan Keadilan, Sebuah Kajian Filsafat Hukum, Jakarta: Prenada Media Group, 2012.

Shihab, M. Quraish, Tafsir al Misbah, Vol. IX. Jakarta: Lentera Hati, 2005, Cet. IV.

Sugiyono, Metode Penelitian Kuantitatif, Kualitatif dan $R \& D$ Cet. VI; Bandung: Alfabeta, 2009.

Sunggono, Bambang, Metodologi Penelitian Hukum, PT Grafindo Persada, Cet. V, 2003.

Syarifudin, Amir, Hukum Perkawinan Islam di Indonesia, Antara Fiqh Munakahat dan Undang-Undang Perkawinan, Cet. II; Jakarta: Prenada Media, 2007.

Undang-Undang Dasar 1945, Amandemen Ke- III.

Undang-Undang Nomor 1 Tahun 1974, Tentang Perkawinan.

Undang-Undang Nomor 7 Tahun 1989, Pasal 49 Tentang Peradilan Agama.

Usman, Rahmadi, Pilihan Penyelesaian Sengketa di Luar pengadilan Bandung, PT. Citra Aditya Bakti, 2003.

Laporan Perkara Pengadilan Agama Donggala Kelas IB Tahun 2017.

Laporan Perkara Pengadilan Agama Parigi Kelas II Tahun 2017.

Laporan Perkara Pengadilan Agama Buol Kelas II Tahun 2017.

Laporan Perkara Pengadilan Agama Bungku Kelas II Tahun 2017. 